\title{
Phenotypic and Molecular Detection of Macrolide Lincosamide Streptogramin B Resistance in Clinical Isolates of Staphylococci
}

\section{Klinik Örneklerden İzole Edilen Stafilokoklarda Makrolid Linkozamid Streptogramin B Direncinin Fenotipik ve Genotipik Olarak Araștırılması}

\author{
Güliz UYAR GÜLEÇ̣(IID), Serkan ÖNCÜ'(ID), Bülent BOZDOG̃AN²(ID), Barçın ÖZTÜRK'(ID), \\ Bülent ERTUG̃RUL'(ID), Serhan SAKARYA'(ID)
}

\footnotetext{
${ }^{1}$ Department of Infectious Diseases and Clinical Microbiology, Faculty of Medicine, University of Adnan Menderes, Aydın, Turkey

${ }^{2}$ Department of Medical Microbiology, Faculty of Medicine, University of Adnan Menderes, Aydın, Turkey
}

Cite this article as: Uyar Güleç G, Öncü S, Bozdoğan B, Öztürk B, Ertuğrul B, Sakarya S. Phenotypic and molecular detection of macrolide lincosamide streptogramin B resistance in clinical isolates of staphylococci. FLORA 2020;25(2):190-6.

\begin{abstract}
Introduction: Macrolide, lincosamide, and streptogramin $B\left(M L S_{B}\right)$ antibiotics are commonly used in the treatment of staphylococcal infections. Some genes like erm, msr, and Inu confer resistance to these group antibiotics. Resistance phenotype can be one of the constitutive, inducible or efflux phenotypes. Resistance rates have been reported at varying rates from various countries. This study aimed to detect $M L S_{B}$ resistance rates, phenotypes, and genotypes in clinical isolates of both Staphylococcus aureus and coagulase-negative staphylococci (CNS).

Materials and Methods: A total of 82 staphylococci strains comprising 65.8\% ( $n=54)$ S. aureus and 34.2\% ( $n=28)$ CNS were identified by conventional methods and 16S rRNA polymerase chain reaction (PCR). Antibiotic susceptibility testing for erythromycin, lincomycin, gentamicin, fusidic acid, levofloxacin, vancomycin, and linezolid was performed by minimum inhibitory concentration (MIC) agar dilution method. Double-disc diffusion test (D-test) was applied to investigate $M L S_{B}$ resistance phenotypes. In erythromycin-resistant isolates, PCR was used to detect the presence of ermA, ermB, ermC, and msrA genes.

Results: Among 54 S. aureus strains, 51\% ( $n=28)$ were methicillin-resistant and 49\% ( $n=26)$ were methicillin-susceptible. Among 28 CNS, 50\% ( $n=14)$ were methicillin-resistant. Erythromycin, lincomycin, gentamicin, and levofloxacin resistance rates were higher in the methicillin-resistant group $(p<0.05)$. Erythromycin resistance rate was $54.9 \%$. Rates of constitutive and inducible $M L S_{B}$ and $M S_{B}$ phenotypes were $30.5 \%, 18.3 \%$, and $6.1 \%$, respectively. The most prevalent resistance determinants were ermA (32.9\%) and ermC (7.3\%). In addition, gene combinations were detected.

Conclusion: Due to the wide geographic distribution of resistance phenotypes and genotypes, local statistics are of critical value for empiric therapy. Double-disc diffusion test is useful to guide interpretation of the susceptibility test.
\end{abstract}

Key Words: D-test; erm genes; $M L S_{B}$ resistance; Staphylococci 
ÖZ

\title{
Klinik Örneklerden İzole Edilen Stafilokoklarda Makrolid Linkozamid Streptogramin B Direncinin Fenotipik ve Genotipik Olarak Araștırılması
}

\author{
Güliz UYAR GÜLEÇ1, Serkan ÖNCÜ1, Bülent BOZDOG̃AN², Barçın ÖZTÜRK!' \\ Bülent ERTUG̃RUL', Serhan SAKARYA ${ }^{1}$ \\ ${ }^{1}$ Adnan Menderes Üniversitesi Tıp Fakültesi, İnfeksiyon Hastalıkları ve Klinik Mikrobiyoloji Anabilim Dalı, Aydın, Türkiye
${ }^{2}$ Adnan Menderes Üniversitesi Tıp Fakültesi, Tıbbi Mikrobiyoloji Anabilim Dalı, Aydın, Türkiye
}

Giriş: Makrolid, linkozamid ve streptogramin $B\left(M L S_{B}\right)$ grubu antibiyotikler stafilokokal infeksiyonların tedavisinde sıklıkla kullanılmaktadır. erm, msr, Inu gibi bazı genler bu grup antibiyotik direncinden sorumlu genlerdir. Direnç yapısal, indüklenebilir ya da efluks fenotipinde olabilir. Direnç oranları farklı ülkelerden farklı oranlarda bildirilmektedir. Bu çalısmada, klinik örneklerden izole edilen Staphylococcus aureus ve koagülaz-negatif stafilokok (KNS) suşlarında $M L S_{B}$ direnç oranlarını, direncin fenotipik ve genotipik özelliklerini saptamayı amaçladık.

Materyal ve Metod: Toplam 82 stafilokok suşunun konvansiyonel yöntemler ve $16 \mathrm{~S}$ rRNA polimeraz zincir reaksiyonu (PCR) yöntemi kullanılarak \%65.8 ( $n=54)^{\prime}$ 'i S. aureus, \%34.2 ( $\left.n=28\right)$ 'si KNS olarak tanımlandı. Eritromisin, linkomisin, gentamisin, fusidik asit, levofloksasin, vankomisin ve linezolid için antibiyotik duyarlııkları minimum inhibitör konsantrasyonu (MiK) agar dilüsyon yöntemi ile belirlendi. $M L S_{B}$ direnç fenotiplerini belirlemek için çift disk testi (D-test) uygulandı. Eritromisine dirençli suşlarda ermA, ermB, ermC ve msra genlerini saptamak için PCR kullanıldı.

Bulgular: Elli dört S. aureus suşunun \%51 ( $n=28)^{\prime}$ 'i metisiline dirençli, \%49 ( $\left.n=26\right)^{\prime} u$ metisiline duyarlı idi. Yirmi sekiz KNS suşunun $\% 50$ ( $n=14$ )'si de metisiline dirençli bulunmuştur. Eritromisin, linkomisin, gentamisin ve levofloksasin direnç oranları metisiline dirençli grupta daha yüksek tespit edilmiştir $(p<0.05)$. Eritromisin direnç oranı \%54.9 olarak saptanmıstır. Yapısal, indüklenebilir ve efluks fenotip oranları \%30.5, \%18.3 ve \%6.1 olarak bulunmuştur. En sık saptanan direnç genleri ermA (\%32.9) ve ermC (\%7.3) olmuştur. Ayrıca gen kombinasyonları da saptanmıştır.

Sonuç: Direnç fenotip ve genotipindeki geniş coğrafik dağııımdan dolayı ampirik tedavi seçimlerinde yerel istatistiklerin bilinmesi kritik değerdedir. Duyarlıık testinin yorumlanmasında çift disk difüzyon testi yol göstericidir.

Anahtar Kelimeler: D-test; erm genleri; $M L S_{B}$ direnci; Stafilokok

\section{INTRODUCTION}

Macrolide, lincosamide and streptogramin $\mathrm{B}$ $\left(\mathrm{MLS}_{\mathrm{B}}\right)$ antibiotics are structurally distinct but affect protein synthesis by similar mechanisms ${ }^{[1]}$. During the elongation phase, they stimulate dissociation of the peptidyl-tRNA from the ribosomes which results in reversible inhibition of protein synthesis ${ }^{[2]}$.

Staphylococcal infections in commmunity and hospital-settings are common. Although newer antibiotics have been developed, clindamycin with its excellent pharmacokinetic properties provides a good treatment option for methicillin-susceptible as well as resistant staphylococci ${ }^{[1]}$. Additionally, clindamycin is an alternative for penicillin-allergic patients $^{[3]}$.

In staphylococci, resistance to $\mathrm{MLS}_{\mathrm{B}}$ antibiotics can occur one of the target site modification, efflux or drug inactivation mechanisms ${ }^{[4]}$. erm genes encode methylases that cause conformational modification of $23 \mathrm{~S}$ rRNA and as a consequence of methylation binding of $\mathrm{MLS}_{\mathrm{B}}$ antibiotics to their target is impaired ${ }^{[5]}$. Efflux which is controlled by the msrA gene (conferring resistance to macrolides and streptogramin B, MSB phenotype) and inactivation of lincosamides by a chemical modification which is mediated by $\ln u \mathrm{~A}$ gene are other mechanisms ${ }^{[6]}$.

Expression of $\mathrm{MLS}_{\mathrm{B}}$ resistance can be inducible $\left(\mathrm{iMLS}_{\mathrm{B}}\right)$ or constitutive $\left(\mathrm{CMLS}_{\mathrm{B}}\right)^{[7]}$. In $\mathrm{iMLS}_{\mathrm{B}}$ resistance, methylase is produced in the presence of an inducing agent, which causes resistance to 14-membered and 15-membered-ring macrolides. However, staphylococci, with an $\mathrm{iMLS}_{\mathrm{B}}$ resistance phenotype are susceptible to lincosamides, streptogramin $\mathrm{B}$, and 16-membered macrolides ${ }^{[6]}$. 
Mutations in the 5' upstream sequences of the erm gene lead to continuous producing of the methylase, and bacteria are resistant to all macrolides, lincosamides and streptogramin $\mathrm{B}^{[6,8]}$.

A double-disk test called D-test is performed for distinguishing inducible erm mediated resistance from msrA mediated efflux mechanism ${ }^{[7]}$. Erythromycin is an effective inducer. Erythromycin and clindamycin disks are placed on an agar plate. Erythromycin resistance and a flattening of the clindamycin inhibition zone proximal to the erythromycin disk produce letter $\mathrm{D}$ shape inhibition zone. This is considered a positive D-test, inducible $\mathrm{MLS}_{\mathrm{B}}$ resistance. Both erythromycin and clindamycin resistant phenotypes are called constitutive $\mathrm{MLS}_{\mathrm{B}}$ resistance. Erythromycin resistant but clindamycin susceptible isolates are considered to have an efflux phenotype $\left(\mathrm{MS}_{\mathrm{B}}\right)^{[5,8,9]}$.

Four major erm genes are detected in pathogenic microorganisms: ermA, ermB, erm $\mathrm{C}$, and ermF, ermA and erm $\mathrm{C}$ are typical staphylococcal gene classes ${ }^{[4]}$.

Since there was no previous study in our province, we aimed to investigate the macrolide resistance rates, the $M L S_{B}$ resistance phenotypes and the genes responsible for resistance in staphylococci isolated in our hospital by polymerase chain reaction (PCR).

\section{MATERIALS and METHODS}

\section{Bacterial Isolates}

Staphylococci, which were accepted as pathogenic and isolated from various clinical specimens (wound, catheter, respiratory secretion, pus, intraabdominal, joint and pleural fluids), were collected from August 2008 to July 2009 in our Infectious Diseases and Clinical Microbiology laboratory. One isolate from each patient was used in the study. A total of 82 staphylococci were identified by conventional methods as Staphylococcus aureus and coagulase-negative staphylococci (CNS). All isolates were identified to the species level using 16s rRNA sequencing.

\section{Antibiotic Susceptibility Test}

Antibiotic susceptibility testing for erythromycin and lincomycin was performed by the minimum inhibitory concentration (MIC) agar dilution met- hod. Also, gentamicin, fusidic acid, levofloxacin, vancomycin and linezolid susceptibilities were determined by the same method. Methicillin resistance was determined by disk diffusion method with cefoxitin. According to the Clinical and Laboratory Standards Institute (CLSI) breakpoints, resistance zone diameter was $<24 \mathrm{~mm}$ for $\mathrm{CNS}$ other than Staphylococcus lugdunensis and $<21$ $\mathrm{mm}$ for $S$. aureus and $S$. lugdunensis ${ }^{[10]}$. Quality control was performed with $S$. aureus ATCC 25923.

\section{Identification of $\mathrm{MLS}_{\mathrm{B}}$ Phenotype by D-test}

$\mathrm{MLS}_{\mathrm{B}}$ resistance phenotypes were investigated using the D-test. A 0.5 McFarland suspension was prepared in sterile distilled water for each isolate and inoculated on the blood agar plate. $2 \mu \mathrm{g}$ clindamycin and $15 \mu \mathrm{g}$ erythromycin disks were placed $15-20 \mathrm{~mm}$ apart. Plates were read after $18 \mathrm{~h}$ of incubation at $35^{\circ} \mathrm{C}$. Flattening of the clindamycin zone of inhibition proximal to the erythromycin disk indicated an inducible type, while resistance to both erythromycin and clindamycin indicated a constitutive $\mathrm{MLS}_{\mathrm{B}}$ resistance. In erythromycin-resistant and clindamycin susceptible isolates, lack of a $\mathrm{D}$ shaped zone was considered as an $\mathrm{MS}_{\mathrm{B}}$ efflux phenotype.

\section{Detection of Resistance Mechanism in Erythromycin-Resistant Strains by PCR}

In erythromycin-resistant isolates, PCR was used to detect the presence of ermA, ermB, erm $\mathrm{C}$ and msrA genes. DNAs were extracted from samples using the InstaGene matrix (Bio$\operatorname{Rad}^{\circledR}$ ) according to the manufacturer's protocol. Colonies from overnight grown plates were suspended in $100 \mu \mathrm{L}$ of sterile distilled water and centrifugated at $10000-12000 \mathrm{rpm}$ for $1 \mathrm{~min}$. The supernatant was carefully removed and the pellet was suspended in $200 \mu \mathrm{L}$ of InstaGene matrix and vortexed, followed by heating at $56^{\circ} \mathrm{C}$ for $15 \mathrm{~min}$. The samples were vortexed again and heated at $100^{\circ} \mathrm{C}$ for $8 \mathrm{~min}$ and then centrifuged to pellet the matrix. Aliquots of $2 \mu \mathrm{L}$ were used as templates for PCR.

The presence of the methylase genes ermA, ermB, and erm $\mathrm{C}$ and of the efflux gene msrA in the isolates studied was confirmed by PCR 
Table 1. Primers specific for ermA, ermB, ermC, and msrA

\begin{tabular}{llc} 
Primer name & Primer sequence & Size of PCR product (bp) \\
\hline ermA1 & 5'-TCT-AAA-AAG-CAT-GTA-AAA-GAA-3' & 645 \\
ermA2 & 5'-CTT-CGA-TAG-TTT-ATT-AAT-ATT-AGT-3' & 639 \\
ermB1 & 5'-GAA-AAG-GTA-CTC-AAC-CAA-ATA-3' & \\
ermB2 & 5'-AGT-AAC-GGT-ACT-TAA-ATT-GTT-TAC-3' & 642 \\
ermC1 & 5'-TCA-AAA-CAT-AAT-ATA-GAT-AAA-3' & \\
ermC2 & 5'-GCT-AAT-ATT-GTT-TAA-ATC-GTC-AAT-3' & 399 \\
$m s r A 1$ & 5'-GCA-AAT-GGT-GTA-GGT-AAG-ACA-ACT-3' & \\
$m s r A 2$ & 5'-ATC-ATG-TGA-TGT-AAA-CAA-AAT-3' &
\end{tabular}

as described previously by Sutcliffe et al. ${ }^{[11]}$ PCR amplification of erm and msr genes was performed with primers specific for ermA, ermB, ermC, and msrA (Table 1). PCR consisted of an initial denaturation at $94^{\circ} \mathrm{C}$ for $5 \mathrm{~min} ; 35$ cycles of denaturation $\left(93^{\circ} \mathrm{C}, 30 \mathrm{~min}\right)$, annealing $\left(50^{\circ} \mathrm{C}\right.$, $30 \mathrm{sec}$, for ermA and $52^{\circ} \mathrm{C}, 1 \mathrm{~min}$ for ermB, $50^{\circ} \mathrm{C}, 1 \mathrm{~min}$, for erm $)$, and extension $\left(72^{\circ} \mathrm{C}, 1\right.$ min); and a final extension at $72^{\circ} \mathrm{C}$ for $7 \mathrm{~min}$. PCR products were separated on $1.5 \%$ agarose gels stained with ethidium bromide and visualized under UV light.

\section{Statistical Analysis}

Statistical analysis was performed using SPSS version 15.0 (SPSS Inc., USA). Counts and percentages were used to summarize the results. Nominal variables were compared using the Chi-Square test. When a $\mathrm{p}$ value was found less than 0.05 , the result was considered as statistically significant and the null hypothesis was rejected.

\section{RESULTS}

Among the 82 isolates studied, 65.8\% $(\mathrm{n}=$ $54)$ were $S$. aureus, $34.2 \%(n=28)$ were CNS. CNS were Staphylococcus epidermidis $(\mathrm{n}=23)$, Staphylococcus haemolyticus $(\mathrm{n}=1)$, Staphylococcus hominis $(\mathrm{n}=1)$, Staphylococcus lugdunensis $(\mathrm{n}=1)$, Staphylococcus simulans $(\mathrm{n}=1)$, and Staphylococcus warneri $(\mathrm{n}=1)$. Among $54 \mathrm{~S}$. aureus strains, $51 \%(\mathrm{n}=28)$ were methicillin-resistant and $49 \%(n=26)$ were methicillin-susceptible. Among $28 \mathrm{CNS}, 50 \%(\mathrm{n}=14)$ were methicillin-resistant.
According to MIC agar dilution results, 41.5\% ( $n=34)$ of the isolates were sensitive to either erythromycin or clindamycin. Erythromycin-sensitive and lincomycin-resistant isolates were $3.6 \%$ ( $n=$ 3). Resistance was detected to erythromycin as $54.9 \%(n=45)$ and to lincomycin as $35.4 \%(n=$ 29). Resistance to erythromycin and lincomycin were higher in methicillin-resistant strains as compared to methicillin-sensitive strains. Of the $45 \mathrm{er}-$ ythromycin-resistant isolates, $44.5 \%(n=20)$ were methicillin-resistant $S$. aureus (MRSA), 13.4\% ( $\mathrm{n}=$ 6) were methicillin-sensitive $S$. aureus (MSSA), $24.5 \% \quad(n=11)$ were methicillin-resistant CNS (MRCNS) and $17.7 \%(n=8)$ were methicillin-sensitive CNS (MSCNS). There was no statistically significant difference between CNS and $S$. aureus in terms of erythromycin resistance $(p=0.089)$.

$18.3 \%(n=15,9 S$. aureus and 6 CNS) of the erythromycin-resistant isolates exhibited inducible phenotype (the D-test positive), whereas 6.1\% ( $\mathrm{n}=5,1 \mathrm{~S}$. aureus and $4 \mathrm{CNS})$ expressed $\mathrm{MS}_{\mathrm{B}}$ phenotype (the D-test negative). Prevalence of $\mathrm{CMLS}_{\mathrm{B}}$ phenotype was $30.5 \%(\mathrm{n}=25,16 \mathrm{~S}$. aureus and $9 \mathrm{CNS}$ ) (Table 2).

The mechanism of resistance responsible for the $\mathrm{MLS}_{\mathrm{B}}$ phenotype was determined by PCR. The prevalence of the resistance genes was detected as ermA $32.9 \%(n=27,20$ S. aureus and $7 \mathrm{CNS})$, ermB $1.2 \%(\mathrm{n}=1, S$. aureus $)$, ermC $7.3 \%(\mathrm{n}=6, \mathrm{CNS})$, msrA $6.1 \%(\mathrm{n}=5,1 \mathrm{~S}$. aureus and $4 \mathrm{CNS}$ ). ermA in combination with ermC was present in $4.9 \%(n=4,3$ S. aureus and $1 \mathrm{CNS}$ ), with msrA was detected in $1.2 \%$ 
Table 2. Distribution of erythromycin-resistant strains according to phenotype, genotype and methicillin susceptibility

\begin{tabular}{|c|c|c|c|c|c|c|c|c|c|c|c|c|c|}
\hline phenotype & & MRSA & & & MSSA & & & MRCNS & & & MSCNS & & \\
\hline genotype & $\mathrm{CMLS}_{\mathrm{B}}$ & $\mathrm{iMLS}_{\mathrm{B}}$ & $\mathrm{MS}_{\mathrm{B}}$ & $\mathrm{CMLS}_{\mathrm{B}}$ & $\mathrm{iMLS}_{\mathrm{B}}$ & $\mathrm{MS}_{\mathrm{B}}$ & $\mathrm{CMLS}_{\mathrm{B}}$ & $\mathrm{iMLS}_{\mathrm{B}}$ & $\mathrm{MS}_{\mathrm{B}}$ & $\mathrm{CMLS}_{\mathrm{B}}$ & $\mathrm{iMLS}_{\mathrm{B}}$ & $\mathrm{MS}_{\mathrm{B}}$ & Total \\
\hline ermA & 8 & 7 & - & 3 & 2 & - & 2 & 2 & - & 2 & 1 & - & 27 \\
\hline ermB & 1 & - & - & - & - & - & - & - & - & - & - & - & 1 \\
\hline ermC & - & - & - & - & - & - & 3 & 1 & - & 1 & 1 & - & 6 \\
\hline msrA & - & - & 1 & - & - & - & - & - & 2 & - & - & 2 & 5 \\
\hline $\operatorname{ermA}+\mathrm{C}$ & 3 & - & - & - & - & - & 1 & - & - & - & - & - & 4 \\
\hline $\begin{array}{l}\operatorname{ermA}+ \\
\mathrm{msrA}\end{array}$ & - & - & - & - & - & - & - & - & - & - & 1 & - & 1 \\
\hline No gene & - & - & - & 1 & - & - & - & - & - & - & - & - & 1 \\
\hline \multirow[t]{2}{*}{ Total } & 12 & 7 & 1 & 4 & 2 & 0 & 6 & 3 & 2 & 3 & 3 & 2 & 45 \\
\hline & & 20 & & & 6 & & & 11 & & & 8 & & \\
\hline
\end{tabular}

MRSA: Methicillin-resistant Staphylococcus aureus, MSSA: Methicillin-sensitive Staphylococcus aureus, MRCNS: Methicillin-resistant coagulase-negative staphylococci, MSCNS: Methicillin-sensitive coagulase-negative staphylococci, $\mathrm{MLS}_{B}$ : Macrolid-lincosamide-streptogramin $B$, c: Constitutive, i: Inducible.

\section{Table 3. Susceptibility of antibiotics according to methicillin susceptibility}

\begin{tabular}{lccc} 
Methicillin susceptibility & $\begin{array}{c}\text { Methicillin-sensitive } \\
(\mathbf{n}=\mathbf{4 0})\end{array}$ & $\begin{array}{c}\text { Methicillin-resistant, } \\
(\mathbf{n}=\mathbf{4 2})\end{array}$ & $\mathbf{p}$ \\
\hline Antibiotics (resistant strain numbers) & & & $<0.001$ \\
Erythromycin & 14 & 31 & 0.030 \\
Lincomycin & 9 & 19 & $<0.001$ \\
Gentamycin & 7 & 30 & 0.073 \\
Fusidic acid & 5 & 12 & $<0.0001$ \\
Levofloxacin & 12 & 39 & 0 \\
Linezolide & 0 & 0 & \\
Vancomycine & 0 & & \\
\hline
\end{tabular}

( $\mathrm{n}=1, \mathrm{CNS})$ of the isolates. No resistance gene was detected in one isolate. The ermC gene was detected only in CNS strains (Table 2).

Of the 15 isolates with an $\mathrm{iMLS}_{\mathrm{B}}$ phenotype, ermA was present in $80 \%(n=12)$, ermC was present $13.4 \%(n=2)$. One $S$. epidermidis isolate contained ermA and msrA and showed an inducible $\mathrm{MLS}_{\mathrm{B}}$ resistance phenotype (6.6\%). Among the 25 isolates with constitutive phenotype, 60\% $(n=15)$ had ermA, 16\% $(n=4)$ had ermC, 16\% $(\mathrm{n}=4)$ had ermA $+\mathrm{C}$ and ermB was present only in $4 \%(n=1)$ of the isolates. All isolates with $\mathrm{MS}_{\mathrm{B}}$ phenotype $(\mathrm{n}=5)$ contained the msrA gene (Table 2).
Distributions of erythromycin-resistant strains according to phenotype, genotype and methicillin-susceptibility are shown in Table 2.

MIC agar dilution results for other examined antibiotics in methicillin-sensitive and -resistant isolates are shown in Table 3. All isolates were susceptible to vancomycin and linezolid.

\section{DISCUSSION}

Inducible resistance to clindamycin is difficult to detect in routine laboratory when D-test is not applied. Strains with the $\mathrm{iMLS}_{\mathrm{B}}$ phenotype are susceptible to clindamycin in vitro. But it is described as clinically resistant to this antibiotic. In such cases, therapeutic failure with clindamycin may occur 
since it can mutate into $\mathrm{cMLS}_{\mathrm{B}}$ during the treatment $^{[11]}$. As a result of mutations occurring in vivo most often within the ermAR regulatory region, located upstream of the coding sequence of the ermA gene, the $\mathrm{cMLS}_{\mathrm{B}}$ phenotype occurs. Mutant strains are selected with clindamycin therapy ${ }^{[12]}$. Therefore, the use of clindamycin in the right indication is important to avoid unnecessary use.

However, $\mathrm{MLS}_{\mathrm{B}}$ resistance rates vary between countries and even hospitals from the same country. In the present study, among the 82 staphylococci, erythromycin resistance rate was 54.9\%. The most prevalent phenotype was $\mathrm{cMLS}_{\mathrm{B}}$, followed by $\mathrm{iMLS}_{\mathrm{B}}$ and $\mathrm{MS}_{\mathrm{B}}$.

In a study from neighboring province including CNS and $S$. aureus strains, the $\mathrm{MS}_{\mathrm{B}}$ phenotype has been found most frequently (42\%) followed by $\mathrm{iMLS}_{\mathrm{B}}(32 \%)$ and $\mathrm{cMLS}_{\mathrm{B}}(26 \%)$ respectively, not similar to our data ${ }^{[13]}$. D-test has been performed for $270 \mathrm{~S}$. aureus in a study from Nepal and the overall prevalence of $\mathrm{iMLS}_{\mathrm{B}}, \mathrm{CMLS}_{\mathrm{B}}$, and $\mathrm{MS}_{\mathrm{B}}$ phenotypes were $11.48 \%$ (31/270), 29.25\% (79/270) and $13.7 \%(37 / 270)$ respectively. Both $\mathrm{iMLS}_{\mathrm{B}}$ and $\mathrm{CMLS}_{\mathrm{B}}$ phenotypes predominated in MRSA strains in accordance with our study ${ }^{[14]}$. Among 71 methicillin-resistant staphylococcal isolates, the $\mathrm{iMLS}_{\mathrm{B}}$ phenotype has been found in $16.6 \%$ of MRSA and $29.2 \%$ of MRCNS, similar to our study ${ }^{[15]}$.

We performed PCR to detect the genes responsible for $\mathrm{MLS}_{\mathrm{B}}$ resistance. ermA was the most prevalent gene with a rate of $32.9 \%$. In another neighboring province, a study has been designed from clinical $S$. aureus isolates. Among 111 isolates showing $\mathrm{iMLS}_{\mathrm{B}}$ phenotype ermA gene has been found in $81.9 \%$ (83 MRSA, 8 MSSA), ermC gene in $10.8 \%$ (7 MRSA, 5 MSSA). Among 19 strains with $\mathrm{cMLS}_{\mathrm{B}}$ phenotype, ermA has been found in 57.9\% (10 MRSA, 1 MSSA), ermC in $36.8 \%$ (6 MRSA, 1 MSSA) and ermB in 15.8\% (3 MRSA) $)^{[16]}$. In contrast to our study, different distribution of $\mathrm{MLS}_{\mathrm{B}}$ resistance phenotypes among S. aureus and CNS isolates in Serbia has been reported by Misic et al. ${ }^{[17]}$. They found that the most frequent phenotype was $\mathrm{iMLS}_{\mathrm{B}}$ (33.4\%) and the second most prevalent was $\mathrm{MS}_{\mathrm{B}}(17.6 \%)$. The most commonly detected $\mathrm{MLS}_{\mathrm{B}}$ resistance genes were $m s r \mathrm{~A} / \mathrm{B}$, followed by erm $\mathrm{C}$, ermB, and ermA ${ }^{[17]}$. In a study from Poland, the most frequ- ent phenotypes and genes were $\mathrm{MS}_{\mathrm{B}}$ and $\mathrm{CMLS}_{\mathrm{B}}$, and ermC among 75 erythromycin-resistant $S$. epidermidis isolates ${ }^{[18]}$. Our findings are in accordance with the studies of Vallianou et al. ${ }^{[19]}$ from Greece and Sedhagat et al. ${ }^{[20]}$ from Iran where $\mathrm{CMLS}_{\mathrm{B}}$ is the predominant resistance phenotype. But erm $\mathrm{C}$ was the most frequently found gene in their study ${ }^{[19,20]}$. A study from Thailand, among 125 erythromycin-resistant CNS, the prevalence of $\mathrm{CMLS}_{\mathrm{B}}, \quad \mathrm{iMLS}_{\mathrm{B}}$ and $\mathrm{MS}_{\mathrm{B}}$ resistance phenotypes was $72 \%, 13.60 \%$ and $14.40 \%$ respectively. These phenotypes were expressed in $80 \%$ of MRCNS strains. The ermC gene (79.20\%) was found to be more prevalent than the ermA gene (22.40\%), especially among $\mathrm{MRCNS}^{[21]}$.

We also evaluated the susceptibilities of some other antibiotics for staphylococci. Considering methicillin susceptibility, other antibiotic resistance rates were found to be high in the methicillin-resistant group. This difference was statistically significant except for fusidic acid $(p=0.073)$. This situation can be explained by the fact that the genetic elements carrying the methicillin resistance genes carry other antibiotic resistance genes.

Due to the wide geographic distribution of resistance phenotypes and genotypes, local statistics are of critical value for empiric therapy. Double-disc diffusion test is useful to guide interpretation of the susceptibility test.

\section{ACKNOWLEDGMENTS}

This research was supported by Adnan Menderes University Research Fund. Project Number: TPF-09009. A special thanks to Can Hüseyin Hekimoğlu, MD for statistical analysis.

\section{ETHICS COMMITTEE APPROVAL}

Ethics committee approval is not required.

\section{CONFLICT of INTEREST}

The authors declare that they have no conflict of interest.

\section{AUTHORSHIP CONTRIBUTIONS}

Concept/Design: GUG, SÖ, BB

Analysis/Interpretation: GUG, BB

Data Acquisition: All of authors

Writting: GUG, SÖ, BB

Final Approval: All of authors 


\section{REFERENCES}

1. Bottega A, Rodrigues MA, Carvalho FA, Wagner TF, Leal IAS, Santos SO, et al. Evaluation of constitutive and inducible resistance to clindamycin in clinical samples of Staphylococcus aureus from a tertiary hospital. Rev Soc Bras Med Trop 2014;47(5):589-92

2. Roberts MC, Sutcliffe J, Courvalin P, Jensen LB, Rood J, Seppala $\mathrm{H}$. Nomenclature for macrolide and macrolide-lincosamide-streptogramin $B$ resistance determinants. Antimicrob Agents Chemother 1999;43(12):2823-30.

3. Jarajreh D, Aqel A, Alzoubi H, Al-Zereini W. Prevalence of inducible clindamycin resistance in methicillin-resistant Staphylococcus aureus: the first study in Jordan. I Infect Dev Ctries 2017;11(4):350-4.

4. Leclercq R. Mechanisms of resistance to macrolides and lincosamides: nature of the resistance elements and their clinical implications. Clin Infect Dis 2002;34(4):482-92.

5. Abbas $A$, Srivastava $P$, Nirwan PS. Prevalence of $M L S_{B}$ resistance and observation of ermA \& ermC genes at a tertiary care hospital. J Clin Diagn Res 2015;9(6):DC08-10.

6. Szczuka E, Makowska N, Bosacka K, Slotwinska A, Kaznowski A. Molecular basis of resistance to macrolides, lincosamides and streptogramins in Staphylococcus hominis strains isolated from clinical specimens. Folia Microbiol (Praha) 2016;61(2):143-7.

7. Lall M, Sahni AK. Prevalence of inducible clindamycin resistance in Staphylococcus aureus isolated from clinical samples. Med J Armed Forces India 2014;70:43-7.

8. Fiebelkorn $K R$, Crawford SA, McElmeel ML, Jorgensen $J H$. Practical disk diffusion method for detection of inducible clindamycin resistance in Staphylococcus aureus and coagulase-negative staphylococci. I Clin Microbiol 2003;41(10):4740-4.

9. Pereira JN, Rabelo MA, Lima JL, Neto AM, Lopes AC, Maciel $M A$. Phenotypic and molecular characterization of resistance to macrolides, lincosamides and type $B$ streptogramin of clinical isolates of Staphylococcus spp. of a university hospital in Recife, Pernambuco, Brazil. Braz J Infect Dis 2016;20(3):276-81

10. CLSI. Performance standards for antimicrobial susceptibility testing; 22nd informational supplement. CLSI M100-S22. Wayne, PA: Clinical and Laboratory Standards Institute, 2012.

11. Sutcliffe J, Grebe T, Tait-Kamradt A, Wondrack L. Detection of erythromycin-resistant determinants by PCR. Antimicrob Agents Chemother 1996;40(11):2562-6.

12. Szymanek-Majchrzak K, Mlynarczyk A, Bilinska M, Rownicki $M$, Majchrzak $K$, Chmura $A$, et al. Effect of selective antibiotic pressure on the MLS-B phenotype in methicillin-resistant Staphylococcus aureus strains originating from patients from transplantation wards: 24 years ofobservations. Transplant Proc 2018;50(7):2164-9.
13. Uzun B, Güngör S, Pektaş B, AksoyGökmen A, Yula E, Koçal $F$, et al. Macrolide-lincosamide-streptogramin $B\left(M L S_{B}\right)$ resistance phenotypes in clinical staphylococcus isolates and investigation of telithromycin activity. Mikrobiyol Bul 2014;48(3):469-76.

14. Adhikari RP, Shrestha S, Barakoti A, Amatya R. Inducible clindamycin and methicillin resistant Staphylococcus aureus in a tertiary care hospital, Kathmandu, Nepal. BMC Infect Dis 2017;17(1):483.

15. Toka-Özer $T$. The rate of inducible $M L S_{B}$ resistance in the methicillin-resistant staphylococci isolated from clinical samples. J Clin Lab Anal 2016;30:490-3.

16. Aydeniz-Ozansoy $F$, Cevahir $N$, Kaleli $i$. Investigation of macrolide, lincosamide and streptogramin $B$ resistance in Staphylococcus aureus strains isolated from clinical samples by phenotypical and genotypical methods. Mikrobiyol Bul 2015;49(1):1-14.

17. Misic M, Cukic J, Vidanovic D, Šekler M, Matic S, Vukasinovic $M$, et al. Prevalence of genotypes that determine resistance of staphylococci to macrolides and lincosamides in Serbia. Front Public Health 2017;5:200.

18. Juda $M$, Chudzik-Rzad B, Malm A. The prevalence of genotypes that determine resistance to macrolides, lincosamides, and streptogramins B compared with spiramycin susceptibility among erythromycin-resistant Staphylococcus epidermidis. Mem Inst Oswaldo Cruz 2016;111(3):155-60.

19. Vallianou $N$, Evangelopoulos A, Hadjisoteriou M, Avlami A, Petrikkos G. Prevalence of macrolide, lincosamide, and streptogramin resistance among staphylococci in a tertiary care hospital in Athens, Greece. I Chemother 2015;27(6):319-23.

20. Sedaghat $H$, Esfahani BN, Mobasherizadeh S, Jazi AS, Halaji M, Sadeghi $P$, et al. Phenotypic and genotypic characterization of macrolide resistance among Staphylococcus aureus isolates in Isfahan, Iran. Iran J Microbiol 2017;9(5):264-70.

21. Teeraputon S, Santanirand P, Wongchai T, Songjang W, Lapsomthob $N$, Jaikrasun $D$, et al. Prevalence of methicillin resistance and macrolide-lincosamide-streptogramin $B$ resistance in Staphylococcus haemolyticus among clinical strains at a tertiary-care hospital in Thailand. New Microbes New Infect 2017;19:28-33.

\section{Address for Correspondence/Yazıșma Adresi}

\section{Dr. Öğr. Üyesi Güliz UYAR GÜLEÇ}

Adnan Menderes Üniversitesi Tip Fakültesi,

İnfeksiyon Hastalıkları ve

Klinik Mikrobiyoloji Anabilim Dalı,

Aydın-Türkiye

E-mail: gulizuyar@yahoo.com 